\title{
RECRUITMENT, SELECTION AND ADAPTATION OF STAFF IN ENTERPRISE
}

doi: $\quad 10.2478 /$ czoto-2019-0129

Date of submission of the article to the Editor: 17/11/2018

Date of acceptance of the article by the Editor: $21 / 01 / 2019$

Piotr Kuryło ${ }^{1}$ - orcid id: 0000-0001-9820-1254

Adam Idzikowski ${ }^{2}$ - orcid id: 0000-0003-1178-8721

Joanna Cyganiuk ${ }^{3}$-orcid id: 0000-0002-7279-0692

Radosław Paduchowicz ${ }^{4}$

1,3 University of Zielona Gora, Poland

${ }^{2}$ Czestochowa University of Technology, Poland, adam.idzikowski@wz.pcz.pl

${ }^{4}$ Sitech, Poland

Abstract: The article discusses and analyses selected issues of selection and adaptation of staff due to the specificity of a company. A theory on the principles of recruitment, selection and adaptation was confronted with the practice applied in a production company, taking into accout the safety of the company, depending on the correct selection of an employee with appropriate competences.

Keywords: recruitment, selection, adaptation, company safety

\section{INTRODUCTION}

The role of knowledge and information is increasingly valued by modern organizations. Intellectual capital is becoming a factor determining the value of an enterprise. Organizations, especially large ones, are increasingly aware of the fact that their competitiveness is determined by human capital, namely: knowledge, skills, competences, innovativeness of employees, as well as the ability of companies to elicit, create and use these resources (Lewicka, 2010).

Issues related to recruitment, selection, adaptation and effective use of knowledge and skills in achieving organizational goals by new employees have been the subject of research and practical solutions for a long time (Pocztowski, 2008) and affect the safety of the company's proper functioning.

A number of materials have been developed on this subject. There are a number of various types of publications, which in a wider or narrower scope, in a more or less detailed way refer to the issues related to recruitment, selection and adaptation of staff. Additionally a growing number of publications are devoted to the employee issues, and the need to improve and develop new management methods for this particular resource has been given are growing attention (Ścibiorek, 2010).

The basic task of the recruitment and selection process is to choose the right person for a particular position. It seems easy, but the paper relates to a long and very complex process that creates the opportunity to make good, but also wrong decisions. 
Thoughtless and wrong decisions in the selection process may have disastrous consequences for the company, including the safety of its functioning. Correcting the wrong decisions usually turns out to be expensive (Dale, 2004). An employee in a wrong position is put in a difficult situation. Frequently new employees blame themselves that their skills are insufficient. They may find it difficult to see that the position they work on was incorrectly described, that unrealistic selection criteria were adopted, or recruiters did not know who they were really looking for (Dale, 2004). Actions taken by the employer to attract and select the best candidate can be compared to taking an investment decision. A person who is responsible for the organization and its culture can become a source of many benefits, whereas a badly chosen employee can become many problems.

The case-study of the process of recruitment, selection and adaptation of staff in a company, has been based on SITECH sp. Z 0.0, a well-prospering and still developing company. This example shall be used to illustrate the issue of selection of appropriate employees, who with their attitude and knowledge can be useful when undertaking tasks in appropriate positions, contributing to the development of the company.

\section{CHARACTERISTICS OF COMPANY SITECH SP. Z O.O.}

The Sitech company manufactures metal racks for car seats and car backs for brands such as: Volkswagen, Audi, Skoda and Seat. The factory in Polkowice employs just under 1,900 employees, both employed under a contract of employment and temporary employees. $78 \%$ of the staff are men, $22 \%$ are women. In terms of education, $28 \%$ of employees have vocational education, the secondary school completed with a matura exam has $44 \%$ of the staff, $20 \%$ employees are university graduates. Only less than $7 \%$ declare primary education. The average age of an employee is 34 years and they are mainly representatives of the local community (Sitech).

\section{SELECTION AND ADAPTATION OF STAFF}

\subsection{Recruitment process}

When planning a recruitment process, the essential question to answer is: "who do we want to employ". First, the requirements for potential candidates must be specified, as well as the tasks to be performed by newly recruited employee must be precisely defined. This is the purpose of a job description. A typical job description includes, in addition to the job title, the scope of basic duties, responsibilities, level of education, desired skills and personality traits. When characterizing the workplace (position), its place in the organizational structure should be determined. A well-designed job description serves to prepare the competence profile of the candidate (Janowska, 2010). Description should attract the attention of the right candidates and at the same time dissuade those who do not meet the requirements from applying for a job (Pocztowski, 2008) and may pose a threat to the company.

The choice of the place where information about the recruitment of candidates is placed may contribute to the success or failure of the advertisement. Each medium has its recipients forming a specific market segment, which should be taken into account (Dale, 2004; Bartakova et al., 2017). The basic task is to deliver messages to the relevant market. 
There are several sources for acquiring candidates at Sitech. When recruiting internally, candidates are informed about vacancies mainly from advertisements placed on information boards and on the intranet. In the case of external recruitment, the methods of acquiring candidates are much wider. The company from Polkowice acquires candidates through online advertisements, employee command systems and through a CV database of candidates on an ongoing basis. Sitech uses the help of a HR consulting agency, whereas online recruitment is currently used by most companies in the world (Bartakova et al., 2017; Vetrakova et al., 2018.)

The company is also present on the Labour Exchanges and Job Fairs, uses the services of a temporary work agency and cooperates with universities, inviting students to internships. An interesting form of acquiring candidates, practised by Sitech, are commands. Sitech has launched a campaign "Become our headhunter". Employees recommend their friends to vacancies in the company.

Undoubtedly, the result of a properly conducted recruitment process should be an appropriate composition of candidates with expected qualifications and skills ready to improve their qualifications (Ścibiorek, 2010).

\subsection{Personnel selection - methods and techniques}

The selection process starts after the candidates submit their applications and the recruitment phase has been completed. The selection is the stage of evaluation of the candidates based on the previously prepared job description and the profile of the candidate.

The goal of selection is to predict whether a given person will be able to satisfactorily cope with situations of specific tasks and requirements at the workplace (Lundy, 2000) and whether it will not pose a threat to the company's functioning and finances. Thus, the selection process involves rejecting applications that do not meet the requirements of a given position. To pick out the best employees, organizations use many methods and selection techniques. The choice of method depends on many factors, and above all, on the type of company, its size, the degree of formalization and the profile of the position the candidate is sought for. In order to make an accurate decision as to the selection method, the following should also be taken into account (Dale, 2004):

1. job description,

2. the impact that the method may have on candidates,

3. the possibility of using the method including:

- costs and required resources (space, material, equipment),

- skills needed to design and apply the method,

- time that candidates and decision makers must spent,

- probability of achieving the desired result.

The mere use of the method is not tantamount to making the right decision, nor does it release decision-makers from responsibility for their decision and its consequences. Selection methods and techniques give a systematic way of collecting information about candidates and help to predict their effectiveness at a given position. Some methods are more effective than others, however, even a good and effective method, if poorly applied, may be useless (Dale, 2004).

At Sitech, the first stage of selection is the application analysis. The main purpose of the initial selection is to reject offers that do not meet the key requirements of the workplace, and thus to create appropriate conditions for further work on the selection 
of the right employees (Ścibiorek, 2010). In other words, the initial selection is to shortlist the candidates for the further selection process. At Sitech, this is the employee of the Personnel Center who makes the preliminary selection of candidates' applications, analyses CVs and cover letters in terms of the job description and competence profile. The practice used by the organization is a telephone conversation with the candidate and verification of basic information, such as foreign language skills, financial expectations, and motivation. Then, the Personnel Center employee passes the selected applications to the HR of Business Partner, who along with the manager of the organizational unit makes further analysis.

One of the basic assessment tools is the interview. The method, seemingly simple, requires a lot of skills and effort to be performed well (Ścibiorek, 2010). It is worth noting though, that some researchers undermine the value of interviews. The main allegation of the method is its subjectivity due to the fact that persons conducting interviews tend to stereotypically group people. Both negative and positive stereotypes may result in unequal and unjust treatment of interlocutors (Lundy, 2000). There are several essential conditions that must be met in order for the interview to be effective and error-free. It is desirable that the interviews are conducted by skilled and experienced persons with professional background in this field. It is important that they are well-versed in the substantive, organizational and technical problems of the company, their management, so that they are able to estimate the candidates' knowledge of these problems, the level of their realism and practicality in their approach to tasks (Adamiec, 2000).

Interviews should be conducted with all candidates according to the same pattern to ensure full objectivity and equal opportunities for all candidates and to avoid low reliability of assessments.

Sitech's practice is to conduct interviews with the participation of an HR representative and the manager of a given organizational unit, although it happens that a larger number of evaluators, e.g. specialists, also take part in the interviews. Thanks to this, it is easy to maintain standards of assessment, recruitment is more friendly to candidates, which fosters building a positive relationship and an open atmosphere during the conversation. Another important stage, although not always used by companies, is the verification of information provided by the candidate. It boils down to contacting people who gave references or a former employer (Ścibiorek, 2010).

Candidates applying for production positions in the Polkowice plant are subjected to manual-competence tests. The screw test is used as a standard, where the candidates' manual skills and concentration are examined. The psychomotor efficiency is checked using the Bourdon test, in which the assessors pay attention mainly to the visual-motor coordination. A lot of attention is placed to group tasks, which help to determine candidates' cooperation skills and communication skills, their care for quality and safety as well as their resistance to stress.

Candidates for specialist positions are subjected to the competence and personality test, i.e. a test of individual advantages and limitations based on the Marston model. On its basis, the profile of natural behaviours is studied: extroverted, introverted, empathy, pragmatism. Also, competences related to interpersonal communication, self-management, decision-making or the ability to work in a group are also examined. On the other hand, based on the test of identification of professional preferences based on the Dalton-Thompson model, individual professional preferences are examined, among others independence, balance in professional and personal life as well as challenges and ambitions. Employees who are candidates for 
a vacant post are also subjected to practical tasks, where their professional competences are examined, their ability to cooperate and communicate, and entrepreneurial thinking and acting. The most frequently used methods to examine the above competences are work samples, scenarios, presentations, knowledge tests, case studies or a basket of tasks. Of course, the selection method depends on the type of position candidates apply for.

The most time-consuming method of the selection of candidates used by Sitech is the assessment centre. Usually the method is used in the final selection stage. Thanks to a combination of different behavioural techniques, candidate's communication, interpersonal and leadership and decision-making skills are assessed. In the subject literature, the assessment centre is considered as the method that best assesses competences relating to thinking, feeling and acting. This technique enables examining the candidate's skills in terms of problem analysing, the ability to think strategically, teamwork skills, influence and planning skills (Janowska, 2010). The most important feature of this method is its relatively high reliability. Exercises are designed to reflect future work and on this basis the desired knowledge, abilities and skills are assessed (Janowska, 2010). It is worth adding that the Sitech company keeps in touch with the applicant from the moment the candidate submits the application for a given position until the selection process is completed.

Wrong choice or incorrectly applied selection method can bring a lot of harm. It increases the risk of signing the work contract with the wrong person, thus reducing the chances for suitable candidates to apply for positions in the future.

\subsection{Adaptation of new employees}

Participation in the organization starts from the moment of making the employment decision. Of course, this decision comes as a result of the positive completion of the recruitment and selection process. Then the new employee enters the organization and the adaptation process begins (Janowska, 2010). It is important that the adaptation process is properly planned and prepared. According to M. Dale's research, it is widely believed that a successful recruitment and selection process, i.e. the company managed to attract and select the best candidate, ensures the promising future for the company. This is a misleading picture. "Many promising candidates are becoming weak employees because the introduction phase has been ignored" (Dale, 2004). Incorrectly carried out adaptation process, or its absence, will cause that the candidate may be reluctant to the company, may cause conflicts and may start looking for another job. Taking into account the costs of recruitment and selection as well as the prospect of incurring further costs related to the search for a new employee, everything should be done to ensure that the adaptation process proceeds properly (Janowska, 2010). When placing an employee in an organization, it is insufficient to have a short conversation with the them or just to hand over the scope of duties. An employee entering the workplace should be provided with care.

Sitech company assumes that a new employee needs to be cared of, as evidenced by the extensive process of personnel adaptation. The inclusion of a newly-admitted employee in the organization is a sensitive process that requires many efforts on the part of the company and carefully developed procedures. This process consists primarily in transferring as soon as possible the patterns of behaviour required from them in the future. The process of adapting a new employee in Sitech lasts 4 months 
and consists of the following stages: appointment of a guardian and preparation of a job position; providing the necessary documents and presenting the Information Brochure; initial training; familiarizing the employee with the workplace; introducing an employee to the department; handing over the Job Description Card; workplace training; integration with the group (optional); research on the effectiveness of the adaptation process.

It is the responsibility of the supervisor to appoint a guardian and his deputy for the new employee. The guardian is responsible for preparing the workplace and for completing the Checklist of the adaptation process. It consists of a dozen control points containing issues that should be passed on to a new employee, among others handing in the work clothing, passes, lockers, preparation of the workplace, or handing in documents (Work Regulations, Information Brochure). An individual training card, which a new person in the organization receives, contains points referring initial trainings, their scope, and people responsible for their implementation.

Initial trainings take place at the workplace and are carried out by internal trainers. The order, duration and persons responsible for conducting the trainings are strictly defined in the initial training schedule. Trainings at Sitech take three days. The initial trainings include issues regarding the company's presentation, its history and missions. The applicable rules of work in the company are clearly defined, the necessary knowledge in the field of health and safety, first aid and environmental protection is provided. On the second day, process issues regarding the philosophy of $5 S$, work with the standard, and ergonomics are presented. On the third day, new employees acquire knowledge of quality assurance issues. The second and third day of training take place in a training center, where new employees acquire basic practical skills.

The newly hired employee on the first day is guided around the workplace, where the most important places are indicated, such as a canteen, bathroom, cloakroom and information on how the departments work. After the "trip", the employee is invited to a sponsored dinner in the company's canteen, a thing unheard of in other companies, and then the employee goes to the warehouse where he/she is given work clothes and a locker.

A proper introduction of a new person consists in verbal information regarding work in the department, team, the explanation of the specificity of the position and the presentation of typical problems occurring in this workplace. The direct superior should inform the employee on the employer's expectations (Ścibiorek, 2010). After handing over the Card of job description to the employee, he/she is bound to take part in a minimum 8hour workplace training within one week from the date when the employee takes up the job position. The workplace training includes the following topics: the knowledge specific for a given workplace, OSH, environmental issues, quality and process issues. The guardian is responsible for these activities. An interesting initiative of the Polkowice plant, although not always practiced by other plants, is the integration of employee groups. Once a year, employees of the company have the possibility, with the consent of the employer, to organize an integration trip, partially financed by the company.

The effectiveness of the personnel adaptation process is examined in the fourth month of employee employment. The process is aided by a list of questions summarizing the adaptation process. This is a set of questions to which the employee 
responds on a 5-point scale. The questions relate to knowledge about the company, awareness of tasks and responsibilities, cooperation with the guardian and the degree of integration with the team. It is worth mentioning that every day after the initial training and after the workplace training the newly admitted employee completes the knowledge test. Information about the new employee is made public on the information board and on the intranet.

\section{CONCLUSIONS}

The process of staff selection and adaptation described above in the company Sitech Sp. z o.o. in Polkowice does not deviate from the mainstream presented in the literature. The basic assumptions of recruitment, selection and adaptation in the company are consistent with the information contained in the professional literature. It is worth showing organizations such as Sitech, which has a formalized procedure for recruiting, selecting and adapting staff, and thus do not operate intuitively. The company strives for continuous improvement through constant examination of the selection and adaptation processes. However, the analysis carried out above suggests considering extending the information campaign on vacancies in the company with the use of the company magazine. To acquire talented, future-oriented, safe for the company employees, it is worth suggesting the employer to work more closely with Universities and to prepare rankings of university graduates (Bartakova et al., 2017). It is also worth to know what are the requirements of future employees (Zaharee et al., 2018). An interesting idea to attract valuable candidates for work is running the "Become our headhunter" program. However, in order to develop the command system, the action should be extended. Namely, if a registered employee is recruited and proves himself/herself as a good employee during the trial period, a money or material reward should await for the "headhunter". The undoubted advantage of this method is saving time and costs devoted to searching for an employee, in addition, the referral takes full responsibility for the recommended person.

Another form of obtaining candidates for work, which may be worth considering, is organizing the so-called open doors, i.e. inviting interested people to get acquainted with the activities of the organization and giving them the opportunity to make the first contact.

At the adaptation stage, the information about the new employee is published on the information board and on the intranet. This formula could be extended with a biographical note of a new employee and a detailed description of his position.

Decisions taken during the recruitment and selection process determine the basis for the subsequent success or failure of the person selected for the position. Presentation of the job requirements and clear job description criteria, personal profile in a transparent way simplify other stages of the process. If mistakes are made at the beginning, painful consequences will be felt by all participants. Proper recruitment and selection, and then the correct adaptation of staff will be perceived as a valuable experience, will encourage the newly employed to demonstrate their abilities. Recruitment and selection is a serious investment that affects the organization's ability to succeed and implement strategic plans. 


\section{REFERENCES}

Adamiec, M., 2000. Kożusznik B.: Zarządzanie zasobami ludzkimi. Wydawnictwo AKADE, Kraków.

Bartakova, G., Gubiniova, K., Brtkova, J., 2017. Actual trends in the recruitment process at small and medium-sized enterprises with the use of social networking. ECONOMIC ANNALS-XXI, 164, 3-4, 80-84 .

Dale, M., 2004. Skuteczna rekrutacja i selekcja pracowników. Oficyna Ekonomiczna, Kraków.

Janowska, Z., 2010. Zarządzanie zasobami ludzkimi. Polskie Wydawnictwo Ekonomicze S.A., Warszawa.

Lewicka, D., 2010. Zarządzanie kapitałem ludzkim w polskich przedsiębiorstwach. PWN, Warszawa.

Kumari, N., 2012. A Study of the Recruitment and Selection process: SMCGlobal. Industrial Engineering Letters, 2/1, 34-43.

Lundy, O., Cowling, A., 2000. Strategiczne zarządzanie zasobami ludzkimi. Oficyna Ekonomiczna, Kraków.

Napathorn, C., 2018. How do social enterprises recruit workers? The case of social enterprises in Thailand. Journal Of Asia Business Studies, 12, 4, 508-532.

Pocztowski, A., 2008. Zarządzanie zasobami ludzkimi. Polskie Wydawnictwo Ekonomiczne, Warszawa.

Puncheva-Michelotti, P., Hudson, S., Jin, G., 2018. Employer branding and CSR communication in online recruitment advertising. Business Horizons, 1, 4, 643-651.

Sitech. Struktura personalna. Dokument opracowany na potrzeby przedsiębiorstwa. Własność Sitech Sp. z o.o.

Ścibiorek, Z., 2010. Zarządzanie zasobami ludzkimi. Difin, Warszawa.

Vetrakova, M., Hitka, M., Potkany, M., et al., 2018. Corporate Sustainability in the Process of Employee Recruitment through Social Networks in Conditions of Slovak Small and Medium Enterprises. Sustainability, 10, 5, 1670.

Zaharee, M., Lipkie, T., Mehlman, S. et al., 2018. Recruitment and Retention of EarlyCareer Technical Talent What Young Employees Want from Employers. ResearchTechnology Management, 61, 5, 51-61. 